\title{
Mitochondrial Amyloid- $\beta$ Levels are Associated with the Extent of Mitochondrial Dysfunction in Different Brain Regions and the Degree of Cognitive Impairment in Alzheimer's Transgenic Mice
}

\author{
Natasa Dragicevic ${ }^{\mathrm{a}}$, Malgorzata Mamcarz ${ }^{\mathrm{a}}$, Yuyan Zhu ${ }^{\mathrm{b}}$, Robert Buzzeo $^{\mathrm{a}}$, Jun Tan ${ }^{\mathrm{b}}$, \\ Gary W. Arendash ${ }^{\mathrm{a}, \mathrm{c}}$ and Patrick C. Bradshaw ${ }^{\mathrm{a}, *}$ \\ ${ }^{a}$ Department of Cell Biology, Microbiology, and Molecular Biology, University of South Florida, Tampa, FL, USA \\ ${ }^{\mathrm{b}}$ Department of Psychiatry and Behavioral Medicine, Sam \& Geri Rashid Laboratory for Developmental \\ Neurobiology, Silver Child Development Center, University of South Florida College of Medicine, Tampa, FL, USA \\ ${ }^{\mathrm{c}}$ The Florida Alzheimer's Disease Research Center, Tampa, FL, USA
}

Accepted 17 April 2010

\begin{abstract}
Mitochondrial dysfunction is observed in Alzheimer's disease (AD) brain, and the amyloid- $\beta$ (A $\beta$ ) peptide is known to induce mitochondrial dysfunction. The relative degree of mitochondrial dysfunction in different regions of the brain in AD is not completely understood. Moreover, the relationship between levels of synaptic mitochondrial $\mathrm{A} \beta$ and mitochondrial dysfunction has not been clearly established. Therefore synaptic and nonsynaptic mitochondria were isolated from the hippocampus, cortex, striatum, and amygdala of 12 month $\mathrm{A} \beta \mathrm{PPsw}$ and $\mathrm{A} \beta \mathrm{PP}+\mathrm{PS} 1$ mouse models of $\mathrm{AD}$ as well as nontransgenic mice. Mitochondrial respiratory rates, reactive oxygen species production, membrane potential, and cytochrome c oxidase activity were measured. Hippocampal and cortical mitochondria showed the highest levels of mitochondrial dysfunction, while striatal mitochondria were moderately affected, and amygdalar mitochondria were minimally affected. Mitochondria from A $\beta$ PP/PS1 brain regions were more impaired than those from $\mathrm{A} \beta \mathrm{PP}$ mice. Mitochondrial $\mathrm{A} \beta$ levels nearly mirrored the extent of mitochondrial dysfunction. Synaptic mitochondria were more impaired than nonsynaptic mitochondria in the AD mouse models. The A $\beta$ PP/PS1 mice showed more impairment in the cognitive interference task of working memory than the A $\beta \mathrm{PP}$ mice. The association between mitochondrial $\mathrm{A} \beta$ levels and mitochondrial dysfunction in mouse models of $\mathrm{AD}$ supports a primary role for mitochondrial $\mathrm{A} \beta$ in $\mathrm{AD}$ pathology. Moreover, the degree of cognitive impairment in $\mathrm{AD}$ transgenic mice can be linked to the extent of synaptic mitochondrial dysfunction and mitochondrial $\mathrm{A} \beta$ levels, suggesting that a mitochondrial $\mathrm{A} \beta$-induced signaling cascade may contribute to cognitive impairment. Therapeutics that target this cascade could be beneficial in the treatment of AD.
\end{abstract}

Keywords: Alzheimer's disease, amygdala, cognitive function, cytochrome oxidase, membrane potential, mitochondrial, reactive oxygen species, respiration, striatum, synapse

\section{INTRODUCTION}

Synapses may be the sites where the neurodegenerative process is initiated in Alzheimer's disease (AD) [1,

${ }^{*}$ Correspondence to: Patrick C. Bradshaw, Department of Cell Biology, Microbiology, and Molecular Biology, University of South Florida, 4202 E. Fowler Ave.; BSF 218, Tampa, Florida, USA. Tel.: +1 813974 6180; Fax: +1 813974 1614; E-mail: pbradsha@cas.usf. edu. 2]. Synaptic dysfunction in both the neocortex and hippocampus is a prominent event in AD progression [35]. In $\mathrm{AD}$ patients, the extent of cognitive decline is very tightly associated with the extent of synaptic loss 
in these specific brain regions [6,7]. Mitochondria are essential for proper synaptic function and mitochondrial dysfunction is another prominent event in AD. However, the precise molecular changes that occur at synaptic terminals in $\mathrm{AD}$, and whether these changes are a direct result of $\mathrm{AD}$-associated mitochondrial dysfunction are not yet known.

An abundance of mitochondria has been the hallmark of synapses since their first ultrastructural description over 50 years ago. Light microscopy provided evidence that the synaptic terminals of axons contain a high density of mitochondria. Mitochondria were further shown to be essential for synaptic form and function in many systems, but it has not been clear exactly what role(s) they play in neurotransmission. Studies of neurons using electron microscopy helped localize synapses in the nervous system based on their abundance of mitochondria [8], and decades later, this feature of preand postsynaptic regions is fully established. A high density of synaptic mitochondria is needed to generate the large amounts of ATP required to fuel synaptic vesicle physiology. Synapses also require mitochondria to take up and buffer cytoplasmic $\mathrm{Ca}^{2+}$ because of the abundance of calcium channels and glutamatergic receptors in these regions. Studies conducted in vertebrate and invertebrate systems have shown that mitochondria and their $\mathrm{Ca}^{2+}$ transport activities are crucial for neurotransmission [9]. Therefore mitochondria play an important role in the overall function of synaptic regions.

Familial AD is predominately caused by mutations in three genes, presenilin-1 (PS1), presenilin-2 (PS2), and amyloid- $\beta$ protein precursor (A $\beta \mathrm{PP})$. PS1 or PS2 and other proteins together form the $\gamma$-secretase complex, which is an intramembrane protease. $\gamma$-secretase, together with $\mathrm{BACE} 1$, the $\beta$-secretase, cleave $\mathrm{A} \beta \mathrm{PP}$ into a toxic amyloid- $\beta$ (A $\beta$ ) peptide fragment. $\mathrm{A} \beta$, a 39-43 amino acid peptide, is a principal constituent of senile plaques and is thought to play a pivotal role in the pathogenesis of AD. A $\beta$ causes cell death when it is administered to cultured neurons. $\mathrm{A} \beta$ is also found intracellularly [10] and aggregation of $\mathrm{A} \beta$ into an oligomeric form is particularly cytotoxic [11], leading to apoptotic neuronal cell death [12-14].

Several pathophysiological events such as apoptosis, disruption of $\mathrm{Ca}^{2+}$ homeostasis, and mitochondrial dysfunction occur in AD brain [15-17]. Mitochondrial dysfunction in $\mathrm{AD}$ is characterized by decreased cytochrome c oxidase (COX) activity, increased reactive oxidative species (ROS) generation, and altered activities of Krebs cycle enzymes such as $\alpha$-ketoglutarate dehydrogenase and pyruvate dehydrogenase [17-20]. These events may be, in part, caused by a direct effect of $\mathrm{A} \beta$ on mitochondria, since $\mathrm{A} \beta$ causes mitochondrial dysfunction when added to isolated mitochondria [21]. Increased intracellular $\mathrm{A} \beta$ levels may also facilitate mitochondrial permeability transition opening [22], a key event in cell death. Therefore, $\mathrm{A} \beta$ can directly disrupt mitochondrial function and contribute to the metabolic deficiencies and loss of synaptic and neuronal function observed in AD patient brains [23]. However, other proteins associated with AD pathology including tau, and apolipoprotein E4 are also partially localized to mitochondria [24-26]. The extent of damage caused by these proteins at the organelle level has not been fully explored, but overexpression of mutant tau has been shown to decrease complex I activity of the mitochondrial electron transport chain [26]. Complex IV of the electron transport chain may be particularly vulnerable in $\mathrm{AD}$ patients since it is a direct target of both $\mathrm{A} \beta$ and a proteolytic fragment of apolipoprotein E4 [24-27].

Familial Alzheimer's mutant A $\beta$ PP overexpression in mouse brain has been shown to cause increased mitochondrial ROS production [28,29], decreased mitochondrial membrane potential and respiration [21], and altered mitochondrial morphology [30]. $\mathrm{A} \beta$ has been localized in synaptic brain mitochondria and likely caused these manifestations [31,32]. Mitochondrial dysfunction and increased oxidative stress occur as early events in these transgenic AD mice, even before the onset of insoluble $\mathrm{A} \beta$ plaque pathology [33-35]. Therefore, mitochondrial dysfunction may at least be partly responsible for other downstream events in AD progression such as synaptic loss and cognitive impairment.

In this study, synaptic and nonsynaptic mitochondria from the cortex, hippocampus, striatum, and amygdala of $\mathrm{A} \beta \mathrm{PP}, \mathrm{A} \beta \mathrm{PP} / \mathrm{PS} 1$, and control mice were isolated. The levels of synaptic mitochondrial $\mathrm{A} \beta$ and the function of the mitochondria from these brain regions were compared to not only determine any regional brain differences in mitochondrial function, but also to elucidate the relationship between mitochondrial $\mathrm{A} \beta$ levels and mitochondrial function in the two AD models investigated.

\section{MATERIALS AND METHODS}

\section{Isolation of synaptic and nonsynaptic brain mitochondria from mice}

All experimental protocols involving animals were 
approved by University of South Florida Animal Use and Care Committee. Mice in this study were derived from the Florida Alzheimer's Disease Research Center mouse colony, wherein heterozygous mice carrying K670N and M671L mutations in the A $\beta$ PP gene are routinely crossed with heterozygous mutant PS1 (M146V; Tg line 6.2) mice to obtain A $\beta$ PP/PS1, A $\beta$ PP, $\mathrm{PS} 1$, and nontransgenic (NT) genotype offspring with a mixed C57/B6/SW/SJL background. In the present study, 12 month old A $\beta$ PP $(n=4), \mathrm{A} \beta \mathrm{PP} / \mathrm{PS} 1$ ( $n=$ 7 ), and littermate NT controls $(n=7)$ were used. Following completion of all behavioral testing, animals were euthanatized using $\mathrm{CO}_{2}$ asphyxiation and decapitated as previously described [36]. First, brains were quickly removed and placed on ice. Brain regions of interest were carefully dissected following anatomical guidelines and placed in a glass Dounce homogenizer containing five times the volume of isolation buffer (215 mM mannitol, $75 \mathrm{mM}$ sucrose, 0.1\% BSA, $1 \mathrm{mM}$ EGTA, $20 \mathrm{mM}$ HEPES $\left(\mathrm{Na}^{+}\right)$, pH 7.2). Following homogenization, the centrifugation procedure from [37] and [38] with slight modifications was used to separate synaptosomes from nonsynaptic mitochondria. After a low-speed spin $(1,300 \times g$ for $5 \mathrm{~min})$ to remove unbroken cells and nuclei, the supernatant was carefully placed in fresh tubes, topped off with isolation buffer, and spun down again at 13,000 x $g$ for $10 \mathrm{~min}$. The resulting pellets were resuspended in a $3 \%$ Percoll (GE Healthcare, Piscataway, NJ) isolation buffer with the supernatant layered on top of a discontinuous Percoll gradient, consisting of layers of $24 \%(3.5 \mathrm{ml}), 15 \%$ $(2 \mathrm{ml})$, and $10 \%(1.5 \mathrm{ml})$ Percoll. The tubes were centrifuged at 32,000 x g for 15 minutes. Nonsynaptic mitochondria formed a pellet at the bottom of the tube and were carefully resuspended in isolation medium and centrifuged again at $13,000 \mathrm{x}$ g to yield purified nonsynaptic mitochondria. Resultant mitochondrial pellets were suspended in isolation buffer without EGTA (215 mM mannitol, $75 \mathrm{mM}$ sucrose, $0.1 \%$ BSA, $20 \mathrm{mM}$ HEPES $\left.\left(\mathrm{Na}^{+}\right), \mathrm{pH} 7.2\right)$ and centrifuged at 16,900 x $g$ for $15 \mathrm{~min}$ and subsequently at $10,000 \mathrm{x} \mathrm{g}$ for $10 \mathrm{~min}$. The final mitochondrial pellet was resuspended in isolation buffer without EGTA at a protein concentration of approximately $10 \mathrm{mg} / \mathrm{ml}$ and kept on ice until experiments were performed. Protein concentration was quantified using a BCA assay. For all mitochondrial analyses, the brain area of interest from 4-7 mice of the same genotype was combined for a single homogenate that was then assayed in triplicate. Experiments were repeated three times.

\section{Respiratory measurements}

The respiratory function of isolated mitochondria was measured using a miniature Clark type oxygen electrode (Strathkelvin Instruments, MT200A chamber, Glasgow, UK). $100 \mu \mathrm{g}(0.3 \mathrm{mg} / \mathrm{ml}$ final concentration) of mitochondria were suspended in a sealed, constantly stirred and thermostatically controlled chamber at $37^{\circ} \mathrm{C}$ containing $350 \mu \mathrm{l}$ of respiration buffer (125 mM KCl, $1 \mathrm{mM} \mathrm{MgCl} 2,2 \mathrm{mM} \mathrm{KH} \mathrm{PO}_{4}, 5 \mathrm{mM}$ pyruvate, $2.5 \mathrm{mM}$ malate, $500 \mu \mathrm{M}$ EGTA, $20 \mathrm{mM}$ HEP$\mathrm{ES}, \mathrm{pH} 7.0)$ at $37^{\circ} \mathrm{C}$. State III respiration was assessed by the addition of $200 \mu \mathrm{M}$ ADP. State IV respiration was achieved by addition of $1 \mu \mathrm{M}$ oligomycin. The respiratory control ratio (RCR) was determined by dividing the rate of oxygen consumption for state III by that of state IV. The rate of oxygen consumption was expressed as nanomoles of $\mathrm{O}_{2}$ per min per milligram of mitochondrial protein.

\section{Reactive oxygen species production}

Mitochondrial ROS production was measured using 2',7'-dichlorodihydrofluorescein diacetate. This compound is cleaved by intramitochondrial esterases and oxidized to fluorescent dichlorofluorescein, (DCF) (excitation $485 \mathrm{~nm}$, emission $530 \mathrm{~nm}$ ) and measured in a Biotek Synergy 2 microplate reader as previously described [36]. $100 \mu \mathrm{g}(0.8 \mathrm{mg} / \mathrm{ml}$ final concentration $)$ of isolated nonsynaptic mitochondria were added to $120 \mu \mathrm{l}$ of KCl-based respiration buffer (see above) with $5 \mathrm{mM}$ pyruvate and $2.5 \mathrm{mM}$ malate added as respiratory substrates and $25 \mu \mathrm{M}$ dichlorodihydrofluorescein diacetate. ROS production was expressed as the DCF fluorescence after a 20 min incubation period and presented in relative fluorescence units. Mitochondrial ROS production in the presence of oligomycin (inducer of increased ROS production) or FCCP (to decrease ROS production) were performed to ensure measurement values were within the range of the indicator.

\section{Mitochondrial membrane potential measurements}

A $200 \mu \mathrm{M}$ solution of JC-1 (5,5',6,6'-tetrachloro1,1',3,3'-tetraethylbenzimidazolyl-carbocyanine iodide) was made using DMSO as the solvent. The assay buffer contained mitochondrial isolation buffer with the addition of $5 \mathrm{mM}$ pyruvate and $5 \mathrm{mM}$ malate. $150 \mu \mathrm{l}$ of assay buffer and $20 \mu \mathrm{l}(1.2 \mathrm{mg} / \mathrm{ml}$ final concentration) of mitochondria were added to the wells of a 96 well black microplate (Corning) followed by addition 
of $1 \mu \mathrm{M} \mathrm{JC}-1$ and mixed gently. The microplate was covered with aluminum foil and left at room temperature for $20 \mathrm{~min}$ before reading. Fluorescence (excitation 530/25 nm, emission 590/30 nm) was measured using a Biotek Synergy 2 multi-mode microplate reader. Fluorescence was expressed in relative fluorescence units.

\section{Mitochondrial $\mathrm{Ca}^{2+}$ uptake}

Mitochondria were suspended at a concentration of $1 \mathrm{mg} / \mathrm{ml}$ in a buffer containing $300 \mathrm{mM}$ mannitol, $5 \mathrm{mM}$ malate, $20 \mathrm{mM}$ pyruvate, $100 \mu \mathrm{M}$ Oregon Green 488 BAPTA-5N $\left(\mathrm{K}^{+}\right), 20 \mu \mathrm{M}$ EGTA, 20 mM HEPES, $\mathrm{pH} 7.2$ at $37^{\circ} \mathrm{C}$ in a black 96-well microplate. $100 \mu \mathrm{M}$ pulses of $\mathrm{CaCl}_{2}$ were injected into each well. A fluorescence excitation filter of $485 / 20 \mathrm{~nm}$ and an emission filter of $528 / 20 \mathrm{~nm}$ were used to monitor extramitochondrial $\mathrm{Ca}^{2+}$ using a Biotek Synergy 2 multi-mode microplate reader.

\section{Cytochrome c oxidase assay}

COX activity was measured using a Clark-type oxygen electrode in the presence of tetramethylphenylenediamine (TMPD) $(250 \mu \mathrm{M})$ and ascorbate $(500 \mu \mathrm{M})$. Mitochondria that had been frozen in 20\% DMSO and then thawed, spun down, and resuspended in isolation buffer were used in this assay. $150 \mu \mathrm{g}(0.4 \mathrm{mg} / \mathrm{ml} \mathrm{fi-}$ nal concentration) of mitochondria were suspended in $350 \mu \mathrm{l}$ of media containing $125 \mathrm{mM} \mathrm{KCl}, 2 \mathrm{mM} \mathrm{MgCl}_{2}$, $2.5 \mathrm{mM} \mathrm{KH}_{2} \mathrm{PO}_{4}, 20 \mathrm{mM}$ HEPES, $\mathrm{pH} 7.0$ in the presence of $1 \mu \mathrm{M}$ FCCP. Ascorbate-reduced TMPD donates electrons directly to COX bypassing the upstream respiratory complexes. Rates of oxygen consumption were calculated before and after addition of TMPD and ascorbate and were expressed as nmol $\mathrm{O}_{2} / \mathrm{min} / \mathrm{mg}$ protein.

\section{A $\beta$ ELISA}

Cortical, hippocampal, striatal and amygdalar mitochondrial levels of total soluble $\mathrm{A} \beta$ were measured by ELISA. Briefly, $20 \mu \mathrm{l}$ of isolated synaptic mitochondrial pellets (final protein concentrations of $10 \mathrm{mg} / \mathrm{ml}$ ) were sonicated for $20 \mathrm{~s}$ and subsequently stored at $-80^{\circ} \mathrm{C}$ for the subsequent determination of total soluble $\mathrm{A} \beta$ levels. Protein levels of mitochondrial homogenate samples were all normalized by BCA protein assay. $\mathrm{A} \beta_{1-40+1-42}$ was quantified in these samples using the $\mathrm{A} \beta_{1-40+1-42}$ ELISA kits in accordance with the manufacturer's instructions. Briefly, 6E10 (capture antibody) was coated at $2 \mathrm{mg} / \mathrm{mL}$ in PBS into 96-well immunoassay plates overnight at $4{ }^{\circ} \mathrm{C}$. The plates were washed with $0.05 \%$ Tween 20 in PBS five times and blocked with blocking buffer (PBS with 1\% BSA, 5\% horse serum) for $2 \mathrm{~h}$ at room temperature. Brain homogenates prepared with lysis buffer by a 1:10 dilution were added to the plates and incubated overnight at $4^{\circ} \mathrm{C}$. Following 3 washes, biotinylated antibody, 4G8 $(0.5 \mathrm{mg} / \mathrm{mL}$ in PBS with $1 \%$ BSA) was added to the plates and incubated for $2 \mathrm{~h}$ at room temperature. After 5 washes, streptavidin-horseradish peroxidase (1:200 dilutions in PBS with 1\% BSA) was added to the 96well plates for $30 \mathrm{~min}$ at room temperature. Tetramethylbenzidine substrate was added to the plates and incubated for $15 \mathrm{~min}$ at room temperature. $50 \mathrm{~mL}$ of stop solution ( $2 \mathrm{~N} \mathrm{H}_{2} \mathrm{SO}_{4}$ ) was added to each well of the plates. The optical density of each well was immediately determined by a microplate reader at $450 \mathrm{~nm}$. Mitochondrial $\mathrm{A} \beta$ levels in brain regions of interest were normalized to zero NT control and expressed as $\mathrm{pg} / \mathrm{mg}$ mitochondrial protein.

\section{Mouse behavioral assessment}

All animals were first evaluated for six days in the radial arm water maze (RAWM) task of working memory, given 4 days of rest, then tested for an additional two days in a more difficult cognitive interference task based on an analogous human task [39].

For RAWM testing, an aluminum insert was placed into a $100 \mathrm{~cm}$ circular pool to create 6 radially distributed swim arms emanating from a central circular swim area. One of the 6 swim arms contained a submerged escape platform ( $9 \mathrm{~cm}$ diameter). The latency and number of errors prior to locating the escape platform was determined for 5 trials per day. Each incorrect arm entry resulted in the animal being pulled back (by the tail) to the start arm for that trial. The platform location was changed daily to a different arm, with different start arms for each of the 5 trials semi-randomly selected from the remaining 5 swim arms. The latency to find the escape platform (maximum $60 \mathrm{~s}$ ) during trials 4 and 5 are both considered indices of working memory and are temporally similar to the standard registration/recall testing of specific items used clinically in evaluating AD patients. Data from the 6 days of testing were statistically analyzed (one-way ANOVA, with post hoc Fisher LSD tests) in three 2-day blocks, with the last block being presented as the most indicative of working memory performance. 

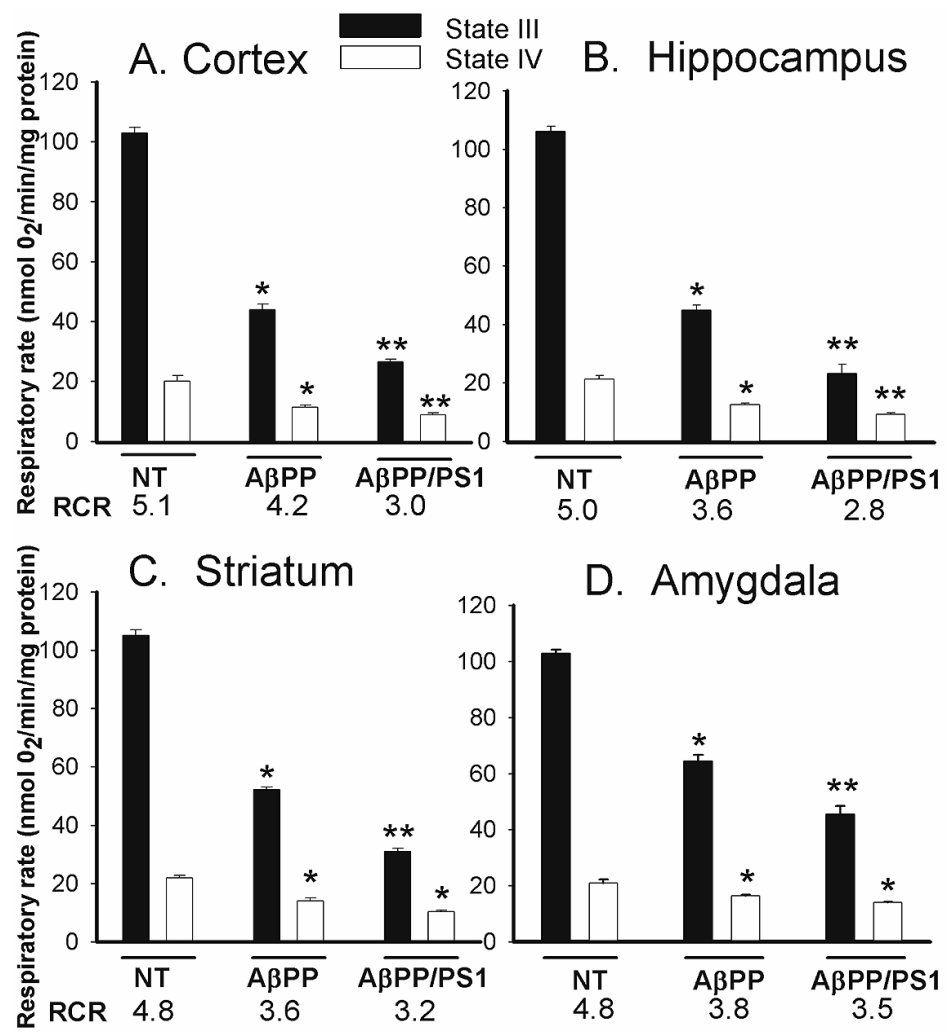

Fig. 1. Decreased State III and State IV respiratory rates and RCR in synaptic mitochondria from A $\beta$ PP and A $\beta$ PP/PS1 transgenic mice. State III and state IV respiratory rates were measured using isolated synaptic mitochondria from the (A) cortex, (B) hippocampus, (C) striatum, or (D) amygdala of NT, A $\beta \mathrm{PP}$, or $\mathrm{A} \beta \mathrm{PP} / \mathrm{PS} 1$ mice $\left({ }^{*} p<0.05\right.$ versus NT, ${ }^{* *} p<0.05$ versus NT and $\mathrm{A} \beta \mathrm{PP}$, Student's $t$-test). The respiratory control ratio (RCR) is indicated below each genotype. The values shown for all figures represent the means \pm S.E.M. from three independent experiments. Each experiment represents a combined homogenate of isolated mitochondria from different brain regions from 5-6 mice.

We designed the cognitive interference task measurefor-measure from a cognitive interference task used to discriminate normal aged, MCI, and AD patients from one another [39]. Our analogous interference task for mice involves two RAWM set-ups in two different rooms, each with different sets of visual cues. The task requires animals to remember a set of visual cues, so that following interference with a different set of cues, the initial set of cues can be recalled to successfully solve the RAWM task. A set of four behavioral measures were examined. Behavioral measures were: A1A3 (Composite three-trial recall score from first 3 trials performed in RAWM “A”), "B" (proactive interference measure attained from a single trial in RAWM "B"), A4 (retroactive interference measure attained during a single trial in RAWM "A"), and "A5" (delayed-recall measure attained from a single trial in RAWM "A" following a 20 min delay between A4 and A5). As a distracter between trials, animals are placed in a Y-maze and allowed to explore for $60 \mathrm{~s}$ between successive trials of the three-trial recall task, as well as during the proactive interference task. As with the standard RAWM task, this interference task involves the platform location being changed daily to a different arm for both of the RAWM set-ups utilized, and different start arms for each day of testing for both RAWM set-ups. For A1 and B trials, the animal was initially allowed one minute to find the platform on their own before they were guided to the platform. Then the actual trial was performed in each case. As with the standard RAWM task, animals were given $60 \mathrm{~s}$ to find the escape platform for each trial, with animals being pulled back to the start arm after entering an incorrect arm, and latency prior to finding the platform recorded for each trial. Animals were tested for cognitive interference performance on two successive days, with statistical analysis performed for the resultant 2-day block. Raw latency data was normalized to percent change in latency to facilitate comparisons across the four measures. Statistical analysis of cognitive interference data involved 


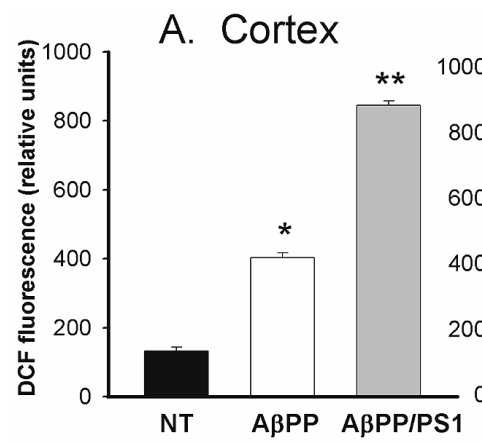

\section{B. Hippocampus}
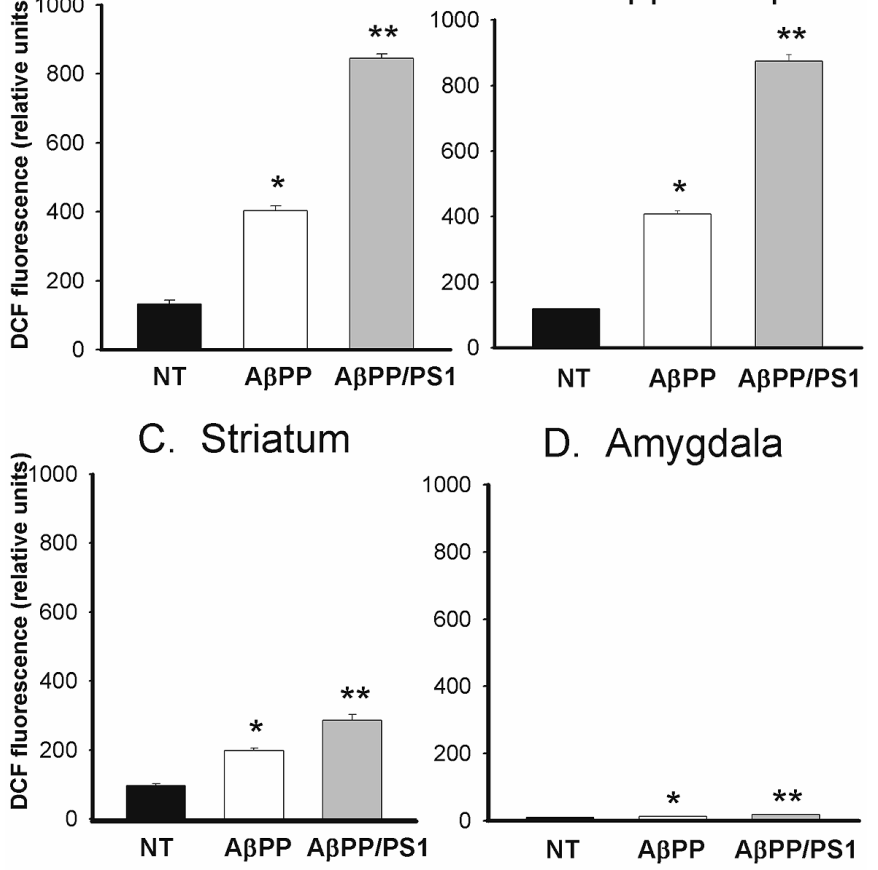

D. Amygdala

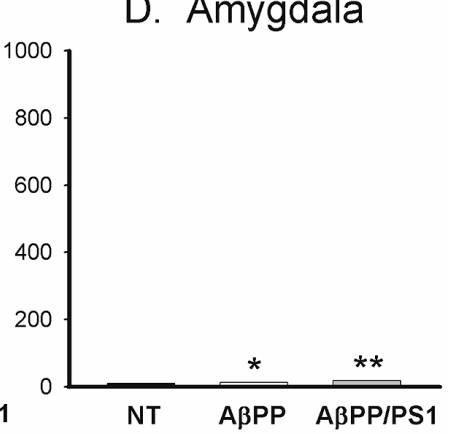

Fig. 2. Synaptic A $\beta$ PP/PS1 and A $\beta$ PP mitochondria produce higher levels of ROS than mitochondria from NT controls. ROS production rates were measured using isolated synaptic mitochondria from the (A) cortex, (B) hippocampus, (C) striatum, or (D) amygdala of NT, A $\beta$ PP, or A $\beta$ PP/PS1 mice $\left({ }^{*} p<0.05\right.$ versus NT, ${ }^{* *} p<0.05$ versus NT and A $\beta$ PP).

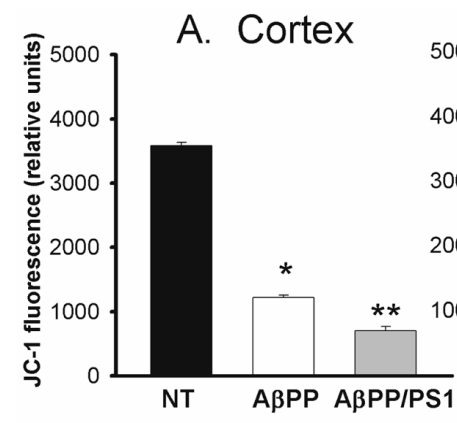

B. Hippocampus

C. Striatum
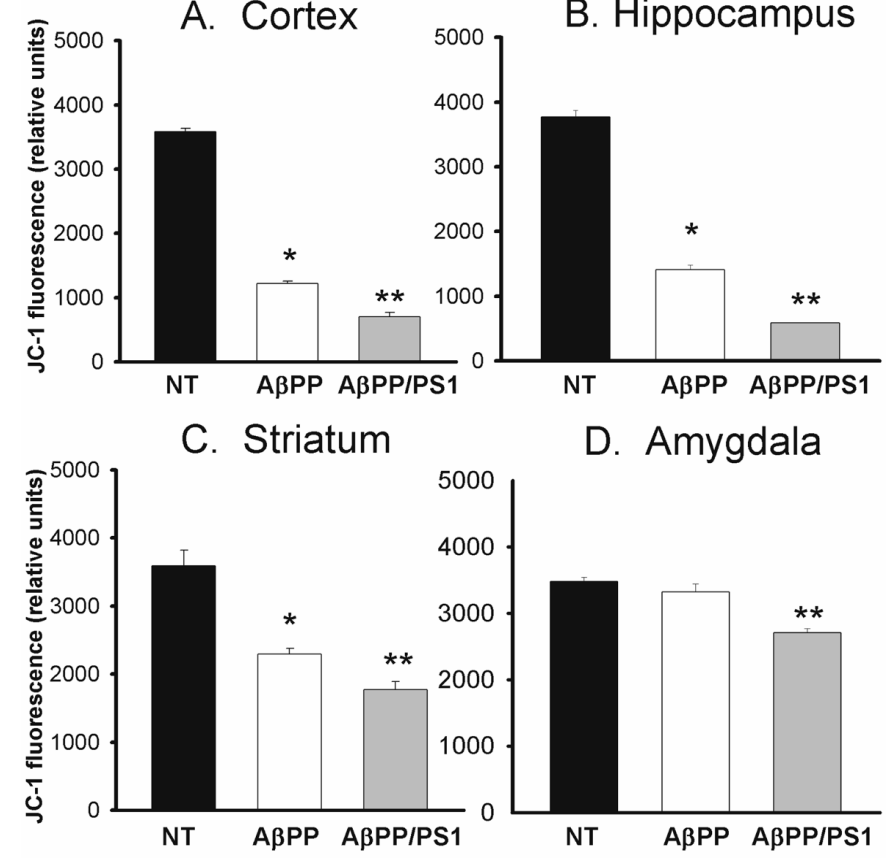

D. Amygdala

Fig. 3. Decreased membrane potential in synaptic mitochondria from A $\beta \mathrm{PP}$ and A $\beta \mathrm{PP} / \mathrm{PS} 1$ mice. The mitochondrial membrane potential was measured in isolated synaptic mitochondria from the (A) cortex, (B) hippocampus, (C) striatum, or (D) amygdala of NT, A $\beta$ PP, or A $\beta$ PP/PS1 mice $\left({ }^{*} p<0.05\right.$ versus NT, ${ }^{* *} p<0.05$ versus NT and A $\left.\beta \mathrm{PP}\right)$. 
initial ANOVAs, followed by post hoc Fisher's LSD tests.

\section{RESULTS}

State III and state IV oxygen consumption rates of isolated synaptic mitochondria from cortex, hippocampus, striatum, and amygdala of $\mathrm{A} \beta \mathrm{PP} / \mathrm{PS} 1, \mathrm{~A} \beta \mathrm{PP}$, and control mice were monitored as shown in Fig. 1. The respiratory control ratio (RCR) (state III/state IV), a measure of the coupling of proton pumping to ATP synthesis, is also shown. Mitochondria from the cerebellum were also analyzed but no $\mathrm{A} \beta \mathrm{PP}$ or PS1related dysfunction was ever found in this region (data not shown). Mitochondria from $\mathrm{A} \beta \mathrm{PP}$ transgenic mice showed reduced state III and state IV respiratory rates compared to NT controls, with mitochondria from $\mathrm{A} \beta \mathrm{PP} / \mathrm{PS} 1$ mice showing even further respiratory dysfunction. However, the difference in state IV respiratory rates between $\mathrm{A} \beta \mathrm{PP}$ and $\mathrm{A} \beta \mathrm{PP} / \mathrm{PS} 1$ striatal and amygdalar mitochondria did not reach statistical significance. Respiratory rates of mitochondria from the hippocampus, cortex, and striatum of $\mathrm{A} \beta \mathrm{PP}$ and $\mathrm{A} \beta \mathrm{PP} / \mathrm{PS} 1$ mice were more impaired than those from the amygdala. This led to a decreased RCR in mitochondria from these three regions compared to that from the amygdala.

Synaptic mitochondria from these same four brain regions were then monitored to assess the rate of ROS production (Fig. 2). Mitochondria from $\mathrm{A} \beta \mathrm{PP}$ mice produced higher levels of ROS than those from NT mitochondria, while A $\beta \mathrm{PP} / \mathrm{PS} 1$ mitochondria generated the highest levels of ROS. In the cortex and hippocampus, A $\beta$ PP mitochondria produced threefold more ROS than NT mitochondria, while $\mathrm{A} \beta \mathrm{PP} / \mathrm{PS} 1$ generated twice the levels of $\mathrm{A} \beta \mathrm{PP}$ mitochondria. $\mathrm{A} \beta \mathrm{PP}$ and $\mathrm{A} \beta \mathrm{PP} / \mathrm{PS} 1$ mitochondria from the striatum were slightly less affected, showing only two and three-fold increases compared to NT controls. Strikingly, NT mitochondria from the amygdala showed a ten-fold decreased ROS production compared to NT mitochondria from the other regions shown. NT cerebellar mitochondria also showed the greatly decreased ROS production rate, similar to that from amygdala (data not shown). Mitochondria from the amygdala of $\mathrm{A} \beta \mathrm{PP}$ and A $\beta$ PP/PS1 were also the least affected by transgene expression, with ROS production levels only doubling in $\mathrm{A} \beta \mathrm{PP} / \mathrm{PS} 1$ mitochondria compared to NT controls.

The mitochondrial membrane potential (MMP) was monitored in isolated mitochondria from mice of the

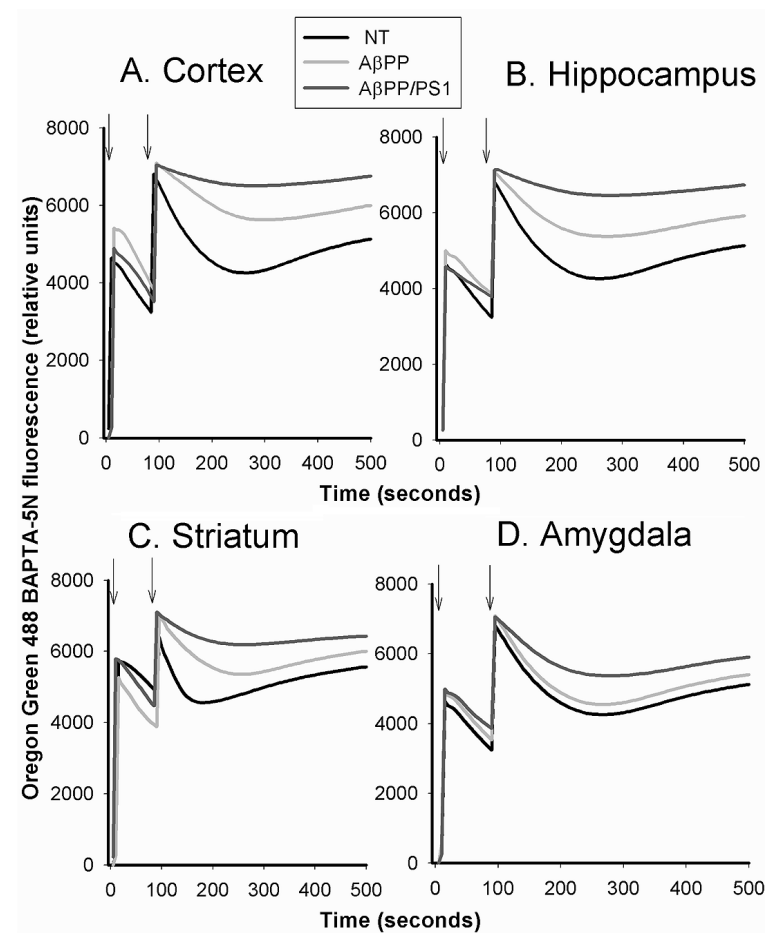

Fig. 4. Calcium uptake by NT, A $\beta$ PP, and A $\beta$ PP/PS1 synaptic mitochondria from different brain regions. Extramitochondrial $\mathrm{Ca}^{2+}$ was monitored over time in isolated synaptic mitochondria from (A) cortex, (B) hippocampus, (C) striatum, or (D) amygdala of NT, $\mathrm{A} \beta \mathrm{PP}$, or $\mathrm{A} \beta \mathrm{PP} / \mathrm{PS} 1$ mice. $100 \mu \mathrm{M} \mathrm{CaCl}_{2}$ was added at each arrow as shown.

three genotypes (Fig. 3). The MMP was decreased in organelles from all four brain regions of $\mathrm{A} \beta \mathrm{PP}$ mice, but the difference was not significant in mitochondria from the amygdala. MMP was further decreased in $\mathrm{A} \beta \mathrm{PP} / \mathrm{PS} 1$ mice in all four brain regions. The hippocampus and cortex were the most affected regions, followed by the striatum, with the amygdalar MMP only slightly decreased. Since MMP is the driving force for calcium uptake into mitochondria, we next monitored calcium uptake into mitochondria from these brain regions (Fig. 4). Unfortunately, the aging of the synaptic mitochondria during the extended isolation procedure caused a dramatic slowdown in mitochondrial calcium uptake rates compared to those observed during the shorter isolation procedure when synaptic and nonsynaptic mitochondria are not separated (data not shown). However, as expected, the calcium uptake rates correlated well with the MMP measurements in the different genotypes of mice.

COX activity in mitochondria from the four brain regions was assayed by monitoring the oxygen consumption rate using TMPD and ascorbate (Fig. 5). Hip- 


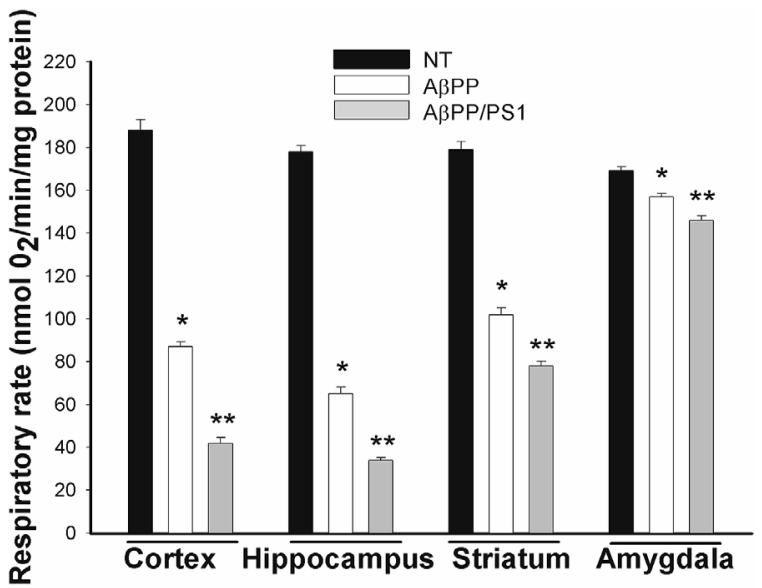

Fig. 5. Decreased cytochrome c oxidase (COX) activity in A $\beta P P$ and $\mathrm{A} \beta \mathrm{PP} / \mathrm{PS} 1$ synaptic mitochondria. COX activity was measured in isolated synaptic mitochondria from the (A) cortex, (B) hippocampus, (C) striatum, or (D) amygdala of NT, $\mathrm{A} \beta \mathrm{PP}$, or $\mathrm{A} \beta \mathrm{PP} / \mathrm{PS} 1$ mice $\left({ }^{*} p<0.05\right.$ versus NT, ${ }^{* *} p<0.05$ versus NT and A $\left.\beta \mathrm{PP}\right)$.

pocampal mitochondria were most affected by transgene expression. A $\beta \mathrm{PP}$ hippocampal mitochondria showed an almost threefold decreased activity, while the activity in $\mathrm{A} \beta \mathrm{PP} / \mathrm{PS} 1$ mitochondria was decreased over fourfold. The cortical mitochondria were nearly as affected. Striatal A $\beta$ PP mitochondrial COX activity was decreased by almost twofold with the activity in A $\beta$ PP/PS1 mitochondria only slightly more affected. Amygdalar A $\beta$ PP and A $\beta$ PP/PS 1 COX activity were only modestly decreased, although significantly so and to a greater extent in $\mathrm{A} \beta \mathrm{PP} / \mathrm{PS} 1$ mice.

Next we assayed total soluble mitochondrial $\mathrm{A} \beta$ levels ( $\mathrm{A} \beta_{1-40}$ and $\mathrm{A} \beta_{1-42}$ ) (Fig. 6). In hippocampus, cortex, and amygdala, $\mathrm{A} \beta \mathrm{PP} / \mathrm{PS} 1$ mitochondria had roughly $50 \%$ more $\mathrm{A} \beta$ than $\mathrm{A} \beta \mathrm{PP}$ mitochondria. However, in the striatum, $\mathrm{A} \beta \mathrm{PP} / \mathrm{PS} 1$ mitochondria had threefold higher levels of $\mathrm{A} \beta$ than $\mathrm{A} \beta \mathrm{PP}$ mitochondria. When comparing mitochondrial $\mathrm{A} \beta$ levels among regions, the cortex and hippocampal fractions had the highest levels; the striatal fraction had roughly three to five fold lower levels; with the amygdalar fraction yielding roughly forty fold lower levels.

Next we determined the differences in respiratory control ratio, ROS production, membrane potential, and COX activity between synaptic and nonsynaptic mitochondria. Figure 7 shows results from hippocampal mitochondria. A $\beta \mathrm{PP}$ and $\mathrm{A} \beta \mathrm{PP} / \mathrm{PS} 1$ synaptic mitochondria showed slightly more dysfunction than nonsynaptic mitochondria in all of these assays. No differences in function were found between nonsynaptic and synaptic mitochondria from nontransgenic control
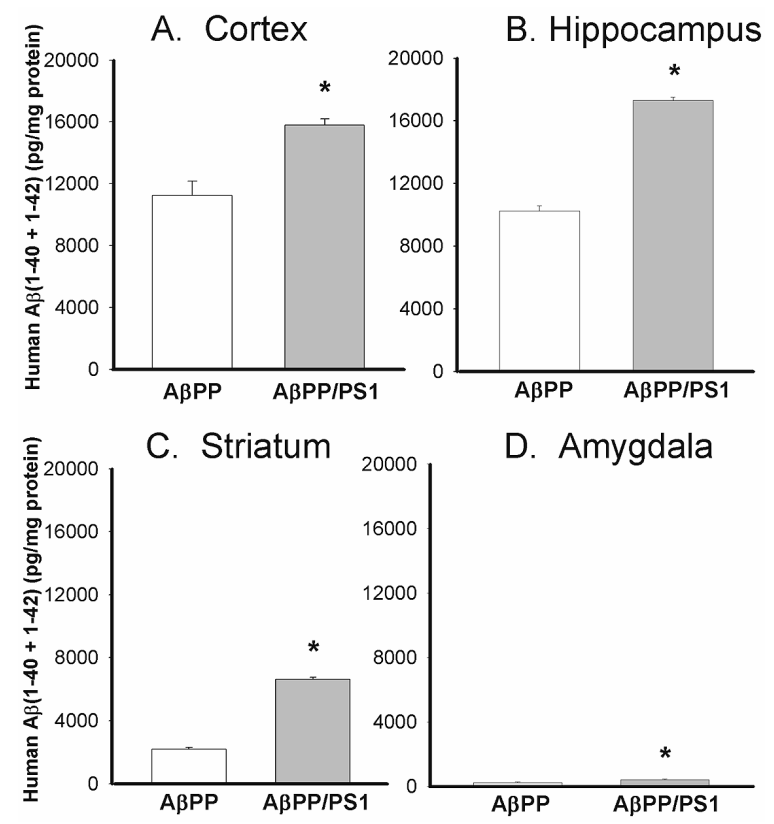

D. Amygdala

Fig. 6. Levels of synaptic mitochondrial $\mathrm{A} \beta$ from different brain regions of $\mathrm{A} \beta \mathrm{PP}$ and $\mathrm{A} \beta \mathrm{PP} / \mathrm{PS} 1$ mice. Human $\mathrm{A} \beta_{1-40,1-42}$ was measured in isolated synaptic mitochondria from the (A) cortex, (B) hippocampus, (C) striatum, or (D) amygdala of $\mathrm{A} \beta \mathrm{PP}$, or $\mathrm{A} \beta \mathrm{PP} / \mathrm{PS} 1$ mice $\left({ }^{*} p<0.05\right.$ versus $\left.\mathrm{A} \beta \mathrm{PP}\right)$.

animals. Similar results were observed for the function of cortical (Fig. 8), striatal (Fig. 9), and amygdalar (Fig. 10) mitochondria, with the relative differences between synaptic and nonsynaptic being slightly smaller in the amygdalar fractions.

Prior to euthanasia and the mitochondrial function analyses, all mice of the three genotypes were subjected to 6 days of working memory evaluation in the RAWM task, followed by 2 days of cognitive interference testing. Analysis of RAWM performance revealed that $\mathrm{A} \beta \mathrm{PP}$ and $\mathrm{A} \beta \mathrm{PP} / \mathrm{PS} 1$ mice were equally impaired in comparison to NT controls, as evidenced by both transgenic groups having high and near-identical escape latencies in Trials 4 and 5 during the final block of behavioral testing (data not shown). The RAWM task was thus unable to behaviorally discriminate between $\mathrm{A} \beta \mathrm{PP}$ and $\mathrm{A} \beta \mathrm{PP} / \mathrm{PS} 1$ genotypes. In sharp contrast, ensuing evaluation of all mice in the more sensitive cognitive interference task (directly analogous to a human cognitive interference task) showed greater impairment of $\mathrm{A} \beta \mathrm{PP} / \mathrm{PS} 1$ mice than $\mathrm{A} \beta \mathrm{PP}$ mice on all four measures of performance (Fig. 11). Specifically, A $\beta$ PP mice were significantly impaired in only one of those four measures (delayed recall) compared to NT controls. However, A $\beta$ PP/PS1 mice were not only impaired in all four measures compared to NT con- 


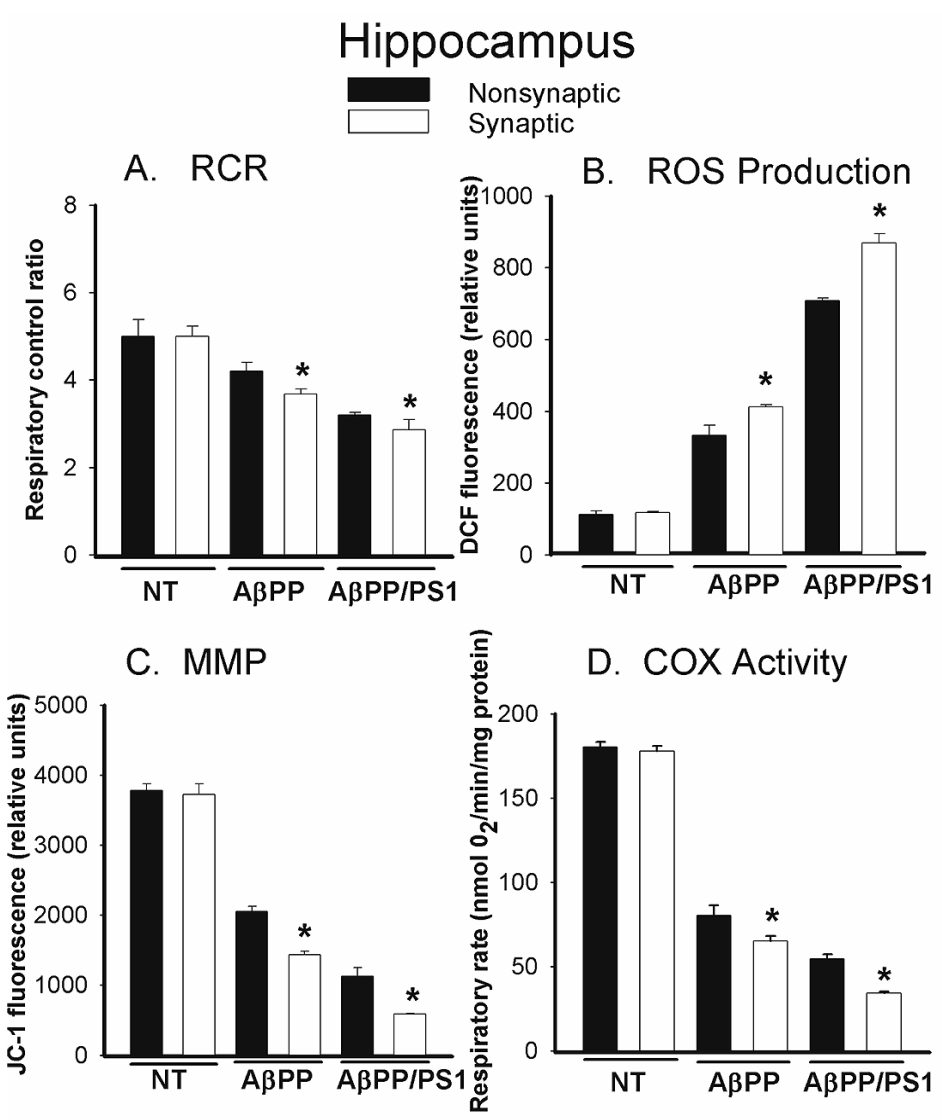

Fig. 7. Hippocampal A $\beta$ PP and A $\beta$ PP/PS1 synaptic mitochondria are more impaired than nonsynaptic mitochondria. Hippocampal nonsynaptic and synaptic mitochondrial (A) respiratory control ratios (RCR), (B) ROS production rates, (C) mitochondrial membrane potential (MMP), and (D) cytochrome c oxidase (COX) activities from NT, A $\beta \mathrm{PP}$, or $\mathrm{A} \beta \mathrm{PP} / \mathrm{PS} 1$ mice are shown $\left({ }^{*} p<0.05\right.$ versus nonsynaptic mitochondria of the same genotype).

trols, but they were significantly more impaired than $\mathrm{A} \beta \mathrm{PP}$ mice on two of the measures (retroactive interference and delayed recall). It is thus apparent that this gradation in cognitive impairment between $\mathrm{A} \beta \mathrm{PP}$ and $\mathrm{A} \beta \mathrm{PP} / \mathrm{PS} 1$ mice mirrored gradations in brain $\mathrm{A} \beta$ levels and mitochondrial dysfunction between these same two genotypes.

\section{DISCUSSION}

To study brain region-specific mitochondrial dysfunction, synaptic and nonsynaptic mitochondria from cortical, hippocampal, striatal, and amygdalar brain regions in $\mathrm{A} \beta \mathrm{PP} / \mathrm{PS} 1, \mathrm{~A} \beta \mathrm{PP}$, and NT mice were isolated and evaluated. Mitochondrial $\mathrm{A} \beta$ levels strongly influenced mitochondrial respiratory function, ROS production rates, and membrane potential in these different brain regions. Mitochondria from the hippocampus and cortex had the highest levels of $\mathrm{A} \beta$ and had the highest degree of mitochondrial dysfunction followed by the striatum, with only a minimal effect on the amygdala. There was also a striking association between mitochondrial impairment and cognitive dysfunction in the $\mathrm{A} \beta \mathrm{PP}$ and $\mathrm{A} \beta \mathrm{PP} / \mathrm{PS} 1$ mice. This is the first demonstration of an association between mitochondrial $\mathrm{A} \beta$ levels and mitochondrial dysfunction in different brain regions and also between these parameters and cognitive impairment in $\mathrm{AD}$ transgenic mice.

It is currently unclear as to what extent mitochondrial dysfunction plays in AD progression. But recent data indicates that mitochondrial $\mathrm{A} \beta$ may be one of several causes of this dysfunction. $\mathrm{A} \beta$ can be transported into mitochondria and is localized in mitochondrial cristae [40]. Within the mitochondrion, $\mathrm{A} \beta$ can bind and inhibit amyloid-binding alcohol dehydrogenase (ABAD) and sensitize the cells to apoptotic stimuli [41]. Some fraction of mitochondrial matrix $A \beta$ may 


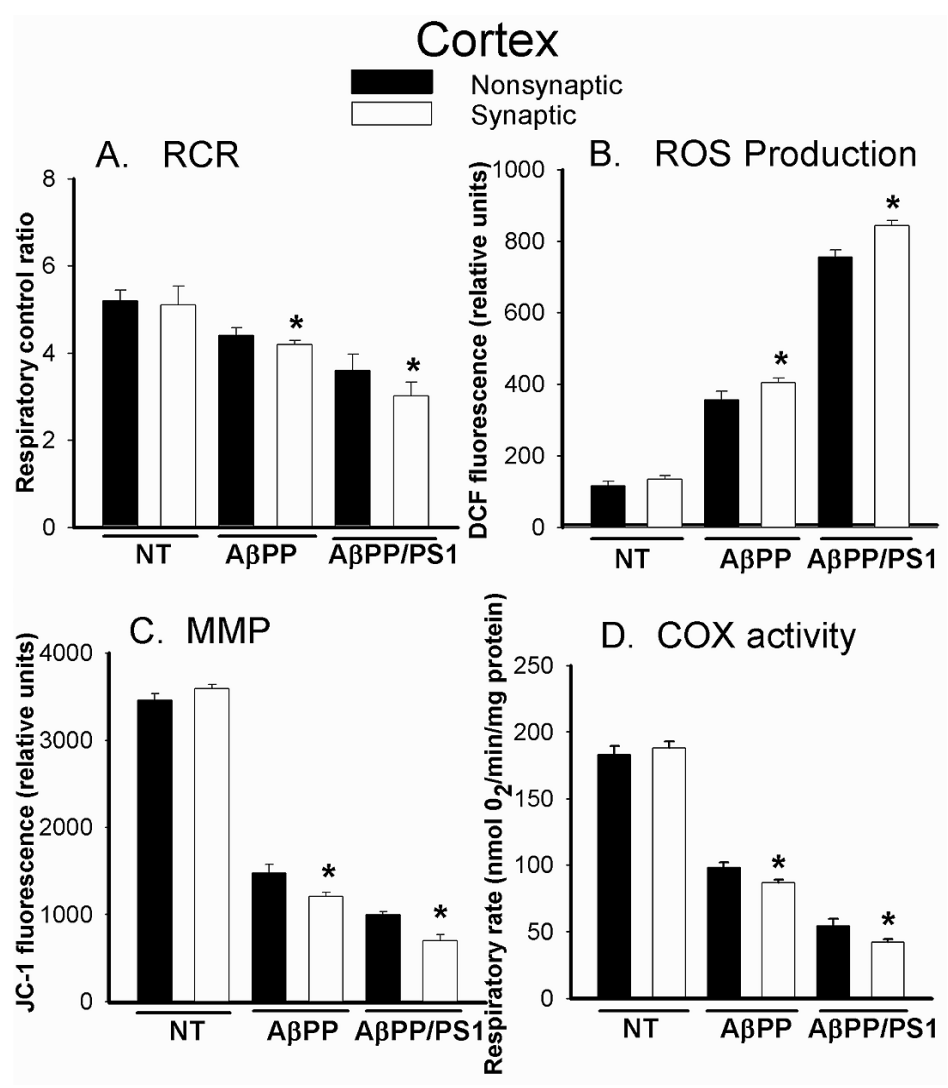

Fig. 8. Cortical synaptic $\mathrm{A} \beta \mathrm{PP}$ and $\mathrm{A} \beta \mathrm{PP} / \mathrm{PS} 1$ mitochondria are more impaired than nonsynaptic mitochondria. Cortical nonsynaptic and synaptic mitochondrial (A) respiratory control ratios (RCR), (B) ROS production rates, (C) mitochondrial membrane potential (MMP), and (D) COX activities from NT, $\mathrm{A} \beta \mathrm{PP}$, or $\mathrm{A} \beta \mathrm{PP} / \mathrm{PS} 1$ mice are shown $\left({ }^{*} p<0.05\right.$ versus nonsynaptic mitochondria of the same genotype).

be degraded by the mitochondrial presequence cleaving peptidasome, PreP [42]. In fact, an interaction between $\mathrm{A} \beta \mathrm{PP}$ and the mitochondrial protein import machinery was shown to inhibit protein import [43]. The decrease in COX activity caused by $\mathrm{A} \beta$ may lead to increased ROS production that damages mitochondrial DNA, proteins, and lipids and could lead to cyclophilin D-dependent permeability transition pore opening and apoptosis [22].

Brain $\mathrm{A} \beta$ levels are known to vary in a regionspecific manner [44]. Intramitochondrial $A \beta$ levels also varied between different brain regions in a similar pattern. Therefore, a steady state equilibrium may exist between cytoplasmic and mitochondrial $\mathrm{A} \beta$. However, the reason for the large variation in $\mathrm{A} \beta$ levels between different parts of the AD brain is still an open question. Expression of $\mathrm{A} \beta \mathrm{PP}$ has been shown to be relatively constant throughout the brain in transgenic mouse models of $\mathrm{A} \beta \mathrm{PP}$ expression, regardless of the promoter used [44]. Likewise $\gamma$-secretase activity is relatively constant throughout the different brain regions $[45,46]$.
BACE expression, responsible for $\beta$-secretase activity, however, was shown to be slightly higher in the hippocampus and cortex than in the cerebellum of wild type mice [47-49]. Conversely, Adam10, the main $\alpha$ secretase, was expressed at slightly higher levels in the cerebellum than the cortex or hippocampus [50]. Although, it seems unlikely that these small differences in secretase activity are the sole reason for the large differences in $\mathrm{A} \beta$ levels, this warrants further investigation. Furthermore, it has been shown that the $\mathrm{A} \beta$ degrading enzymes neprilysin and insulin degrading enzyme are subject to oxidative inactivation [51]. These enzymes may then be the least active in the brain regions that produce the highest levels of mitochondrial ROS. Therefore, the higher levels of hippocampal and cortical $\mathrm{A} \beta$ in $\mathrm{A} \beta \mathrm{PP}$ and $\mathrm{A} \beta \mathrm{PP} / \mathrm{PS} 1$ mice may, in part, be a result of the higher levels of mitochondrial produced ROS in these regions that inactivates $\mathrm{A} \beta$ degrading enzymes.

It is well established that cognitive and synaptic activity are highly reliant on mitochondrial function. Mice administered the COX inhibitor azide showed in- 


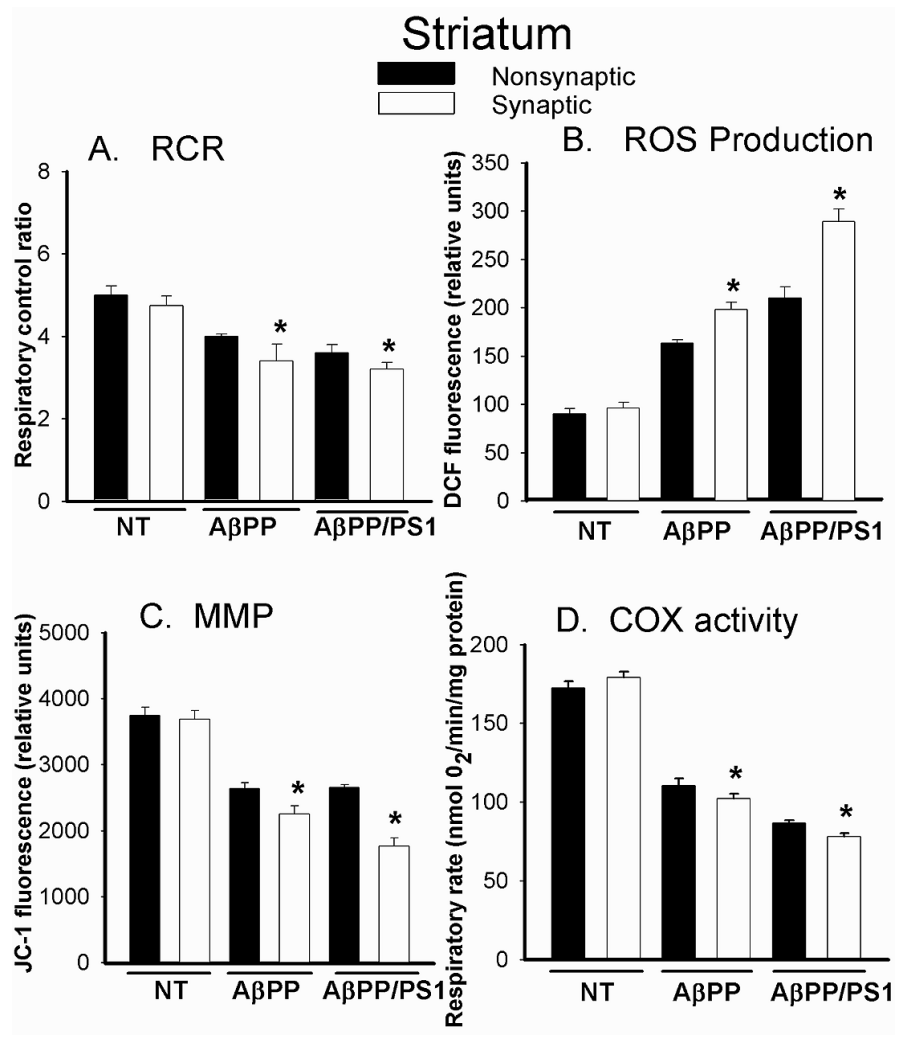

Fig. 9. Striatal synaptic $\mathrm{A} \beta \mathrm{PP}$ and $\mathrm{A} \beta \mathrm{PP} / \mathrm{PS} 1$ mitochondria are more impaired than nonsynaptic mitochondria. Striatal nonsynaptic and synaptic mitochondrial (A) respiratory control ratios (RCR), (B) ROS production rates, (C) mitochondrial membrane potential (MMP), and (D) COX activities from NT, $\mathrm{A} \beta \mathrm{PP}$, or $\mathrm{A} \beta \mathrm{PP} / \mathrm{PS} 1$ mice are shown $\left({ }^{*} p<0.05\right.$ versus nonsynaptic mitochondria of the same genotype).

creased latency to initiate a response in a T-maze [52], impaired spatial learning in the Morris water maze [53], and impaired episodic memory in the object recognition test [54]. COX inhibition was also shown to specifically alter hippocampal cholinergic innervation [54]. In humans, inborn COX deficiency may manifest as Leigh's Syndrome, sometimes symptomized by severe cognitive deficits [55]. Synaptic contacts decrease with normal brain aging and this is associated with decreased COX activity [56]. This may reflect the tight coupling between synaptic and mitochondrial function at the transcriptional level with both COX and NMDA glutamate receptor genes being activated by the transcription factor nuclear respiratory factor 1 (NRF-1) [57]. Together these data indicate that the decreased COX activity from normal aging coupled with the inhibition by $\mathrm{A} \beta$ may lead to the synaptic deficits observed in AD.

In the assays performed, synaptic mitochondrial function was more impaired than that of nonsynaptic mitochondria. There are several possible explanations for this effect. It has been proposed that mi- tochondria at synapses are older than mitochondria in cell bodies [58]. So the greater decrease in mitochondrial function for synaptic mitochondria may just reflect the slightly longer time that $\mathrm{A} \beta$ has interacted with mitochondria at this location. Alternatively, synaptic mitochondria have been shown to have a higher cyclophilin D content than nonsynaptic mitochondria and are thus more prone to permeability transition pore opening [59], which may increase organelle ROS production due to cytochrome c release. Lastly, the increased calcium signaling and localized metabolic stress at the synapse may cause synaptic mitochondria to be more vulnerable to the toxic effects of $\mathrm{A} \beta$.

Mitochondria play an important role in the maintenance of synaptic function. Mitochondrial function at synapses is critical for neurotransmission by generating ATP and maintaining calcium homeostasis $[60,61]$. But mitochondria must first be transported to the synapse. Mitochondrial division occurs in the cell body. Arrival of mitochondria at the synaptic regions occurs via regulated axonal transport [62]. Highly energized mitochondria are thought to be transported to synapses 


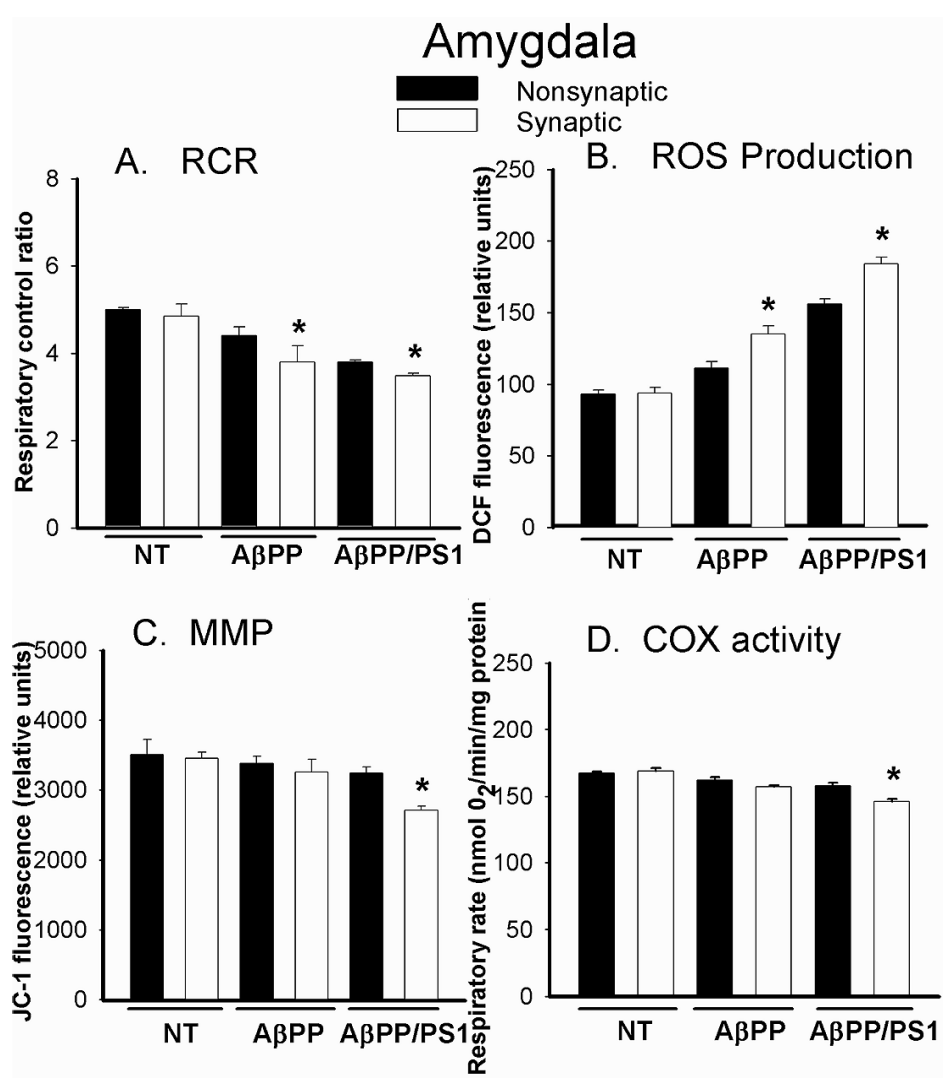

Fig. 10. Amygdalar synaptic $\mathrm{A} \beta \mathrm{PP}$ and $\mathrm{A} \beta \mathrm{PP} / \mathrm{PS} 1$ mitochondria are more impaired than nonsynaptic mitochondria. Amygdalar nonsynaptic and synaptic mitochondrial (A) respiratory control ratios (RCR), (B) ROS production rates, (C) mitochondrial membrane potential (MMP), and (D) COX activities from NT, A $\beta$ PP, or $\mathrm{A} \beta \mathrm{PP} / \mathrm{PS} 1$ mice are shown $\left({ }^{*} p<0.05\right.$ versus nonsynaptic mitochondria of the same genotype).

while damaged mitochondria are transported back to the cell body $[63,64]$. This transport is regulated by MMP and intracellular calcium levels, which are both influenced by $\mathrm{A} \beta$ [65]. When $\mathrm{A} \beta$ was expressed in fruitfly neurons, a slowdown of bi-directional transport of axonal mitochondria was observed. A depletion and enlargement of pre-synaptic mitochondria, as well as a decreased number of synaptic vesicles was seen [66, 67]. This slowed axonal transport combined with the increased oxidative stress caused by $\mathrm{A} \beta$ may lead to synaptic dysfunction.

Autophagy is a process in which double membrane autophagosomes engulf cytoplasm and organelles leading to their eventual degradation. Autophagy is the predominate pathway for mitochondrial degradation and is also important for $\mathrm{A} \beta$ degradation. Autophagic vesicles formed in neurites must be transported back to the cell body where they fuse with lysosomes. The autophagic process in neurons is constituitively active and very efficient so few autophagic vesicles are observed under normal conditions. However, the presence of $\mathrm{A} \beta$ increases the number of autophagome-engulfed mitochondria present in neurites [68]. This is likely due to an increased rate of autophagic sequestration of organelles coupled with a decreased rate of fusion of autophagic vesicles with lysosomes [68]. This disrupted autophagosomal and lysosomal function may play an important role in mitochondrial dysfunction and intracellular $\mathrm{A} \beta$ accumulation in $\mathrm{AD}$.

A decreased number of neuronal mitochondria have been shown in the early stages of AD [69]. Changes in mitochondrial morphology have also been observed in several AD brain regions [70]. This includes an increased amount of fragmented mitochondria [67], which occur as a result of an increase in nitric oxideinduced mitochondrial fission [71]. The increased nitric oxide synthase activity is likely the result of an $\mathrm{A} \beta$-mediated increase in cytoplasmic calcium concentration. Altered rates of mitochondrial fusion or fission in $\mathrm{AD}$ neurons could also explain the decreased number and increased size of mitochondria observed in AD brain and fruitfly neurons expressing $\mathrm{A} \beta[66,72]$. 
It has been suggested that the decreased ATP levels and MMP and increased ROS production resulting from increased $\mathrm{A} \beta$ levels are a direct consequence of altered rates of mitochondrial fusion or fission events, because overexpression of the mitochondrial fusion protein OPA1 was able to partially restore these parameters [67]. Mitochondrial fusion and fission are essential activities because knockout mice devoid of either of these functions suffer from embryonic lethality [73,74]. Neurons, being polarized cells, are especially vulnerable to alterations in mitochondrial fusion and fission. Embryonic neurons from the DRP1 knockout mouse, deficient in mitochondrial fission, showed improper mitochondrial localization, dysfunctional synapse formation, and were more sensitive to apoptotic stimuli [74]. Cells from Mitofusin 1 or Mitofusin2 knockout mice, deficient in mitochondrial fusion, often had a low MMP [75]. Cerebellar mitochondria from mice deficient in Mitofusin2 in that particular brain region had decreased electron transport chain activity and lacked mitochondrial DNA nucleoids. These results indicate that without mitochondrial fusion individual mitochondria in the brain can become deficient in an essential component, such as mitochondrial DNA, in a stochastic manner. A slow rate of mixing of matrix space components between separate mitochondria is therefore essential for neuronal function. $\mathrm{A} \beta$, by altering mitochondrial fission or fusion rates, may slow that rate of mixing below the critical threshold necessary for proper mitochondrial function. However, it is unlikely that altered rates of mitochondrial fusion or fission can explain the mitochondrial dysfunction that occurs following the addition of $\mathrm{A} \beta$ to isolated mitochondria.

It is not entirely clear why $\mathrm{A} \beta \mathrm{PP}$ and $\mathrm{A} \beta \mathrm{PP} / \mathrm{PS} 1 \mathrm{mi}-$ tochondria in synaptic regions were more dysfunctional than mitochondria from other regions of the cell. Perhaps the decreased rates of axonal transport combined with the altered rates of mitochondrial fission or fusion selectively slow the degradation rate of synaptic mitochondria causing accumulation of oxidatively damaged organelles in synapses. Presynaptic mitochondria regulate neurotransmission by taking up and releasing $\mathrm{Ca}^{2+}$ [9]. In addition, high mitochondrial transmembrane potential and/or mitochondrial $\mathrm{Ca}^{2+}$ sequestration are necessary to resist or recover from synaptic depression [76-79], to support post-tetanic potentiation [80], and to prevent asynchronous neurotransmitter release [78]. Moreover, different synapses are shown to have different $\mathrm{Ca}^{2+}$ signaling properties and some of them require more mitochondrial support than others [81]. Therefore, $\mathrm{A} \beta$-mediated mitochondrial dys-

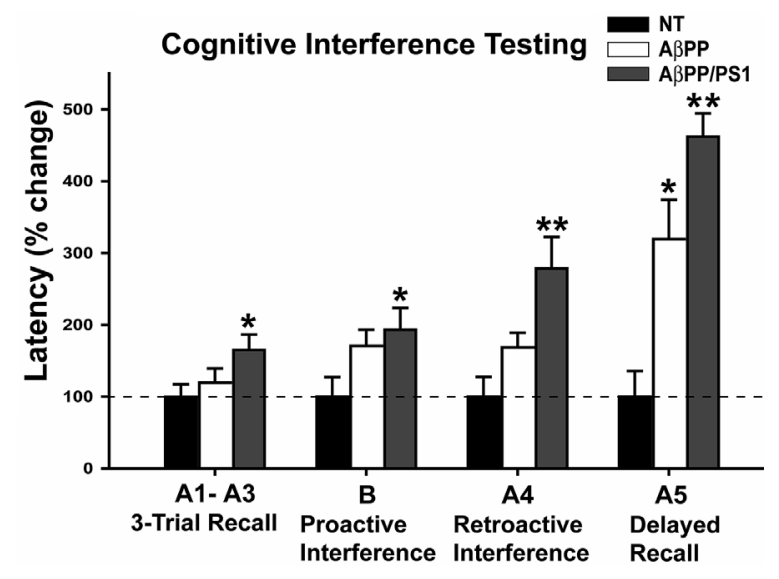

Fig. 11. $\mathrm{A} \beta \mathrm{PP} / \mathrm{PS} 1$ mice are more impaired than $\mathrm{A} \beta \mathrm{PP}$ mice in a cognitive interference task. The mice were behaviorally tested using a cognitive interference task. A $\beta$ PP mice were impaired in only one measure (delayed recall) compared to NT controls, while A $\beta$ PP/PS1 mice were impaired in all four measures $\left({ }^{*} p<0.05\right)$. A $\beta$ PP/PS1 mice also showed greater behavioral impairment in both retroactive interference and delayed recall than $\mathrm{A} \beta \mathrm{PP}$ mice $\left({ }^{* *} p<0.05\right)$.

function likely alters mitochondrial $\mathrm{Ca}^{2+}$ uptake and other $\mathrm{Ca}^{2+}$-dependent cellular processes in a locationspecific manner.

Striatal amyloid and intraneuronal neurofibrillary changes are hallmarks of AD. Numerous amyloid deposits were present in $\mathrm{AD}$ patient striatum, but only rarely encountered in the striatum from nondemented individuals [82-85]. Striatal mitochondria are known to be more susceptible to permeability transition pore opening than those from several other brain regions [86]. Striatal mitochondria are also especially susceptible to energy compromise [87]. Therefore lower $\mathrm{A} \beta$ levels may affect striatal mitochondria more markedly than other regions of the brain and striatal mitochondrial dysfunction may play an under-appreciated role in $\mathrm{AD}$ progression.

A limitation of this study is that mice from only one age were analyzed, so the rates of change of mitochondrial dysfunction over time in these different brain regions are not known. It is known that mitochondrial dysfunction is one of the first measurable phenotypes in transgenic $\mathrm{A} \beta \mathrm{PP}$ mice [88] and that mitochondrial A $\beta$ levels increase substantially at an age when cognitive dysfunction first occurs [89]. Therefore analyzing synaptic and nonsynaptic mitochondrial function at different ages in these different brain regions could provide information on specific molecular changes necessary for cognitive decline. Future studies aim to address this issue. 


\section{ACKNOWLEDGMENTS}

We would like to thank Dr. Chuanhai Cao and Neil Copes for helpful discussion.

Authors' disclosures available online (http://www.jalz.com/disclosures/view.php?id=426).

\section{REFERENCES}

[1] Mattson MP, Liu D (2002) Energetics and oxidative stress in synaptic plasticity and neurodegenerative disorders. Neuromolecular Med 2, 215-231.

[2] Selkoe DJ (2002) Alzheimer's disease is a synaptic failure. Science 298, 789-791.

[3] Bertoni-Freddari C, Fattoretti P, Casoli T, Meier-Ruge W, Ulrich J (1990) Morphological adaptive response of the synaptic junctional zones in the human dentate gyrus during aging and Alzheimer's disease. Brain Res 517, 69-75.

[4] Davies CA, Mann DM, Sumpter PQ, Yates PO (1987) A quantitative morphometric analysis of the neuronal and synaptic content of the frontal and temporal cortex in patients with Alzheimer's disease. J Neurol Sci 78, 151-164.

[5] DeKosky ST, Scheff SW (1990) Synapse loss in frontal cortex biopsies in Alzheimer's disease: correlation with cognitive severity. Ann Neurol 27, 457-464.

[6] Samuel W, Masliah E, Hill LR, Butters N, Terry R (1994) Hippocampal connectivity and Alzheimer's dementia: effects of synapse loss and tangle frequency in a two-component model. Neurology 44, 2081-2088.

[7] Terry RD, Masliah E, Salmon DP, Butters N, DeTeresa R, Hill R, Hansen LA, Katzman R (1991) Physical basis of cognitive alterations in Alzheimer's disease: synapse loss is the major correlate of cognitive impairment. Ann Neurol 30, 572-580.

[8] Palay SL (1956) Synapses in the central nervous system. $J$ Biophys Biochem Cytol 2, 193-202.

[9] David G, Barrett EF (2000) Stimulation-evoked increases in cytosolic $[\mathrm{Ca}(2+)]$ in mouse motor nerve terminals are limited by mitochondrial uptake and are temperature-dependent. $J$ Neurosci 20, 7290-7296.

[10] Hartmann T (1999) Intracellular biology of Alzheimer's disease amyloid beta peptide. Eur Arch Psychiatry Clin Neurosci 249, 291-298.

[11] Pike CJ, Walencewicz AJ, Glabe CG, Cotman CW (1991) Aggregation-related toxicity of synthetic beta-amyloid protein in hippocampal cultures. Eur J Pharmacol 207, 367-368.

[12] LaFerla FM, Tinkle BT, Bieberich CJ, Haudenschild CC, Jay G (1995) The Alzheimer's A beta peptide induces neurodegeneration and apoptotic cell death in transgenic mice. Nat Genet 9, 21-30.

[13] Loo DT, Copani A, Pike CJ, Whittemore ER, Walencewicz AJ, Cotman CW (1993) Apoptosis is induced by beta-amyloid in cultured central nervous system neurons. Proc Natl Acad Sci U S A 90, 7951-7955.

[14] Mattson MP, Partin J, Begley JG (1998) Amyloid beta-peptide induces apoptosis-related events in synapses and dendrites. Brain Res 807, 167-176.

[15] Beal MF (1998) Mitochondrial dysfunction in neurodegenerative diseases. Biochim Biophys Acta 1366, 211-223.

[16] Offen D, Elkon H, Melamed E (2000) Apoptosis as a general cell death pathway in neurodegenerative diseases. $J$ Neural Transm Suppl, 153-166.
[17] Reddy PH, Beal MF (2005) Are mitochondria critical in the pathogenesis of Alzheimer's disease? Brain Res Brain Res Rev 49, 618-632.

[18] Lin MT, Beal MF (2006) Mitochondrial dysfunction and oxidative stress in neurodegenerative diseases. Nature 443, 787 795.

[19] Maurer I, Zierz S, Moller HJ (2000) A selective defect of cytochrome c oxidase is present in brain of Alzheimer disease patients. Neurobiol Aging 21, 455-462.

[20] Parker WD, Jr. (1991) Cytochrome oxidase deficiency in Alzheimer's disease. Ann N Y Acad Sci 640, 59-64.

[21] Casley CS, Canevari L, Land JM, Clark JB, Sharpe MA (2002) Beta-amyloid inhibits integrated mitochondrial respiration and key enzyme activities. J Neurochem 80, 91-100.

[22] Parks JK, Smith TS, Trimmer PA, Bennett JP, Jr., Parker WD, Jr. (2001) Neurotoxic Abeta peptides increase oxidative stress in vivo through NMDA-receptor and nitric-oxide-synthase mechanisms, and inhibit complex IV activity and induce a mitochondrial permeability transition in vitro. J Neurochem $\mathbf{7 6}$ 1050-1056.

[23] Beal MF (2005) Mitochondria take center stage in aging and neurodegeneration. Ann Neurol 58, 495-505.

[24] Chang S, ran Ma T, Miranda RD, Balestra ME, Mahley RW, Huang Y (2005) Lipid- and receptor-binding regions of apolipoprotein E4 fragments act in concert to cause mitochondrial dysfunction and neurotoxicity. Proc Natl Acad Sci U S A 102, 18694-18699.

[25] David DC, Hauptmann S, Scherping I, Schuessel K, Keil U, Rizzu P, Ravid R, Drose S, Brandt U, Muller WE, Eckert A, Gotz J (2005) Proteomic and functional analyses reveal a mitochondrial dysfunction in P301L tau transgenic mice. $J$ Biol Chem 280, 23802-23814.

[26] Rhein V, Song X, Wiesner A, Ittner LM, Baysang G, Meier F, Ozmen L, Bluethmann H, Drose S, Brandt U, Savaskan E, Czech C, Gotz J, Eckert A (2009) Amyloid-beta and tau synergistically impair the oxidative phosphorylation system in triple transgenic Alzheimer's disease mice. Proc Natl Acad Sci U S A 106, 20057-20062.

[27] Crouch PJ, Blake R, Duce JA, Ciccotosto GD, Li QX, Barnham KJ, Curtain CC, Cherny RA, Cappai R, Dyrks T, Masters CL, Trounce IA (2005) Copper-dependent inhibition of human cytochrome c oxidase by a dimeric conformer of amyloidbeta1-42. J Neurosci 25, 672-679.

[28] Li F, Calingasan NY, Yu F, Mauck WM, Toidze M, Almeida CG, Takahashi RH, Carlson GA, Flint Beal M, Lin MT, Gouras GK (2004) Increased plaque burden in brains of APP mutant MnSOD heterozygous knockout mice. J Neurochem 89, 13081312.

[29] Smith MA, Hirai K, Hsiao K, Pappolla MA, Harris PL, Siedlak SL, Tabaton M, Perry G (1998) Amyloid-beta deposition in Alzheimer transgenic mice is associated with oxidative stress. J Neurochem 70, 2212-2215.

[30] Sirk D, Zhu Z, Wadia JS, Shulyakova N, Phan N, Fong J, Mills LR (2007) Chronic exposure to sub-lethal beta-amyloid (Abeta) inhibits the import of nuclear-encoded proteins to mitochondria in differentiated PC12 cells. J Neurochem $\mathbf{1 0 3}$ 1989-2003.

[31] Mungarro-Menchaca X, Ferrera P, Moran J, Arias C (2002) beta-Amyloid peptide induces ultrastructural changes in synaptosomes and potentiates mitochondrial dysfunction in the presence of ryanodine. J Neurosci Res 68, 89-96.

[32] Gillardon F, Rist W, Kussmaul L, Vogel J, Berg M, Danzer K, Kraut N, Hengerer B (2007) Proteomic and functional alter- 
ations in brain mitochondria from $\mathrm{Tg} 2576$ mice occur before amyloid plaque deposition. Proteomics 7, 605-616.

[33] Devi L, Prabhu BM, Galati DF, Avadhani NG, Anandatheerthavarada HK (2006) Accumulation of amyloid precursor protein in the mitochondrial import channels of human Alzheimer's disease brain is associated with mitochondrial dysfunction. J Neurosci 26, 9057-9068.

[34] Eckert A, Hauptmann S, Scherping I, Rhein V, Muller-Spahn F, Gotz J, Muller WE (2008) Soluble beta-amyloid leads to mitochondrial defects in amyloid precursor protein and tau transgenic mice. Neurodegener Dis 5, 157-159.

[35] Manczak M, Anekonda TS, Henson E, Park BS, Quinn J, Reddy PH (2006) Mitochondria are a direct site of A beta accumulation in Alzheimer's disease neurons: implications for free radical generation and oxidative damage in disease progression. Hum Mol Genet 15, 1437-1449.

[36] Brown MR, Geddes JW, Sullivan PG (2004) Brain regionspecific, age-related, alterations in mitochondrial responses to elevated calcium. J Bioenerg Biomembr 36, 401-406.

[37] Dunkley PR, Jarvie PE, Robinson PJ (2008) A rapid Percoll gradient procedure for preparation of synaptosomes. Nat Protoc 3, 1718-1728.

[38] Chandrasekaran K, Hazelton JL, Wang Y, Fiskum G, Kristian T (2006) Neuron-specific conditional expression of a mitochondrially targeted fluorescent protein in mice. $J$ Neurosci 26, 13123-13127.

[39] Loewenstein DA, Acevedo A, Luis C, Crum T, Barker WW, Duara R (2004) Semantic interference deficits and the detection of mild Alzheimer's disease and mild cognitive impairment without dementia. J Int Neuropsychol Soc 10, 91-100.

[40] Hansson Petersen CA, Alikhani N, Behbahani H, Wiehager B, Pavlov PF, Alafuzoff I, Leinonen V, Ito A, Winblad B, Glaser E, Ankarcrona M (2008) The amyloid beta-peptide is imported into mitochondria via the TOM import machinery and localized to mitochondrial cristae. Proc Natl Acad Sci U $S$ A 105, 13145-13150.

[41] Lustbader JW, Cirilli M, Lin C, Xu HW, Takuma K, Wang N, Caspersen C, Chen X, Pollak S, Chaney M, Trinchese F, Liu S, Gunn-Moore F, Lue L-F, Walker DG, Kuppusamy P, Zewier ZL, Arancio O, Stern D, Yan SS, Wu H (2004) ABAD Directly Links A $\{$ beta\} to Mitochondrial Toxicity in Alzheimer's Disease. Science 304, 448-452.

[42] Falkevall A, Alikhani N, Bhushan S, Pavlov PF, Busch K, Johnson KA, Eneqvist T, Tjernberg L, Ankarcrona M, Glaser E (2006) Degradation of the amyloid beta-protein by the novel mitochondrial peptidasome, PreP. J Biol Chem 281, 2909629104.

[43] Anandatheerthavarada HK, Biswas G, Robin MA, Avadhani NG (2003) Mitochondrial targeting and a novel transmembrane arrest of Alzheimer's amyloid precursor protein impairs mitochondrial function in neuronal cells. J Cell Biol 161, 4154.

[44] Johnson-Wood K, Lee M, Motter R, Hu K, Gordon G, Barbour R, Khan K, Gordon M, Tan H, Games D, Lieberburg I, Schenk D, Seubert P, McConlogue L (1997) Amyloid precursor protein processing and $\mathrm{A}$ beta 42 deposition in a transgenic mouse model of Alzheimer disease. Proc Natl Acad Sci U S A 94, 1550-1555.

[45] Hebert SS, Serneels L, Dejaegere T, Horre K, Dabrowski M, Baert V, Annaert W, Hartmann D, De Strooper B (2004) Coordinated and widespread expression of gamma-secretase in vivo: evidence for size and molecular heterogeneity. Neurobiol Dis 17, 260-272.
[46] Siman R, Salidas S (2004) Gamma-secretase subunit composition and distribution in the presenilin wild-type and mutant mouse brain. Neuroscience 129, 615-628.

[47] Bodendorf U, Danner S, Fischer F, Stefani M, Sturchler-Pierrat C, Wiederhold KH, Staufenbiel M, Paganetti P (2002) Expression of human beta-secretase in the mouse brain increases the steady-state level of beta-amyloid. J Neurochem 80, 799-806.

[48] Irizarry MC, Locascio JJ, Hyman BT (2001) beta-site APP cleaving enzyme mRNA expression in APP transgenic mice: anatomical overlap with transgene expression and static levels with aging. Am J Pathol 158, 173-177.

[49] Zohar O, Cavallaro S, D'Agata V, Alkon DL (2003) Quantification and distribution of beta-secretase alternative splice variants in the rat and human brain. Brain Res Mol Brain Res 115, 63-68.

[50] Karkkainen I, Rybnikova E, Pelto-Huikko M, Huovila AP (2000) Metalloprotease-disintegrin (ADAM) genes are widely and differentially expressed in the adult CNS. Mol Cell Neurosci 15, 547-560.

[51] Shinall H, Song ES, Hersh LB (2005) Susceptibility of amyloid beta peptide degrading enzymes to oxidative damage: a potential Alzheimer's disease spiral. Biochemistry 44, 1534515350 .

[52] Lalonde R, Joyal CC, Beaudin S (1997) Effects of sodium azide on motor activity, motor coordination, and learning. Pharmacol Biochem Behav 56, 67-71.

[53] Bennett MC, Rose GM (1992) Chronic sodium azide treatment impairs learning of the Morris water maze task. Behav Neural Biol 58, 72-75.

[54] Luques L, Shoham S, Weinstock M (2007) Chronic brain cytochrome oxidase inhibition selectively alters hippocampal cholinergic innervation and impairs memory: prevention by ladostigil. Exp Neurol 206, 209-219.

[55] Lombes A, Nakase H, Tritschler HJ, Kadenbach B, Bonilla E, DeVivo DC, Schon EA, DiMauro S (1991) Biochemical and molecular analysis of cytochrome c oxidase deficiency in Leigh's syndrome. Neurology 41, 491-498.

[56] Bertoni-Freddari C, Fattoretti P, Casoli T, Di Stefano G, Giorgetti B, Balietti M (2008) Brain aging: The zinc connection. Exp Gerontol 43, 389-393.

[57] Dhar SS, Wong-Riley MT (2009) Coupling of energy metabolism and synaptic transmission at the transcriptional level: role of nuclear respiratory factor 1 in regulating both cytochrome c oxidase and NMDA glutamate receptor subunit genes. J Neurosci 29, 483-492.

[58] Brown MR, Sullivan PG, Geddes JW (2006) Synaptic mitochondria are more susceptible to $\mathrm{Ca} 2+$ overload than nonsynaptic mitochondria. J Biol Chem 281, 11658-11668.

[59] Naga KK, Sullivan PG, Geddes JW (2007) High cyclophilin D content of synaptic mitochondria results in increased vulnerability to permeability transition. $J$ Neurosci $\mathbf{2 7}, \mathbf{7 4 6 9 - 7 4 7 5 .}$

[60] Kann O, Kovacs R (2007) Mitochondria and neuronal activity. Am J Physiol Cell Physiol 292, C641-C657.

[61] Nicholls DG, Budd SL (2000) Mitochondria and neuronal survival. Physiol Rev 80, 315-360.

[62] Hollenbeck PJ (1996) The pattern and mechanism of mitochondrial transport in axons. Front Biosci 1, d91-d102.

[63] Bloom GS, Richards BW, Leopold PL, Ritchey DM, Brady ST (1993) GTP gamma S inhibits organelle transport along axonal microtubules. J Cell Biol 120, 467-476.

[64] Chang DT, Reynolds IJ (2006) Mitochondrial trafficking and morphology in healthy and injured neurons. Prog Neurobiol 80, 241-268. 
[65] Cai Q, Sheng ZH (2009) Mitochondrial transport and docking in axons. Exp Neurol 218, 257-267.

[66] Iijima-Ando K, Hearn SA, Shenton C, Gatt A, Zhao L, Iijima K (2009) Mitochondrial mislocalization underlies Abeta42induced neuronal dysfunction in a Drosophila model of Alzheimer's disease. PLoS One 4, e8310.

[67] Wang X, Su B, Siedlak SL, Moreira PI, Fujioka H, Wang Y, Casadesus G, Zhu X (2008) Amyloid-beta overproduction causes abnormal mitochondrial dynamics via differential modulation of mitochondrial fission/fusion proteins. Proc Natl Acad Sci U S A 105, 19318-19323.

[68] Nixon RA (2007) Autophagy, amyloidogenesis and Alzheimer disease. J Cell Sci 120, 4081-4091.

[69] Hirai K, Aliev G, Nunomura A, Fujioka H, Russell RL, Atwood CS, Johnson AB, Kress Y, Vinters HV, Tabaton M, Shimohama S, Cash AD, Siedlak SL, Harris PL, Jones PK, Petersen RB, Perry G, Smith MA (2001) Mitochondrial abnormalities in Alzheimer's disease. J Neurosci 21, 3017-3023.

[70] Baloyannis SJ (2006) Mitochondrial alterations in Alzheimer's disease. J Alzheimers Dis 9, 119-126.

[71] Cho DH, Nakamura T, Fang J, Cieplak P, Godzik A, Gu Z, Lipton SA (2009) S-nitrosylation of Drp1 mediates beta-amyloidrelated mitochondrial fission and neuronal injury. Science 324, $102-105$

[72] Zhao XL, Wang WA, Tan JX, Huang JK, Zhang X, Zhang BZ, Wang YH, YangCheng HY, Zhu HL, Sun XJ, Huang FD (2010) Expression of beta-amyloid Induced age-dependent presynaptic and axonal changes in Drosophila. J Neurosci 30, 1512-1522.

[73] Chen H, Detmer SA, Ewald AJ, Griffin EE, Fraser SE, Chan DC (2003) Mitofusins Mfn1 and Mfn2 coordinately regulate mitochondrial fusion and are essential for embryonic development. J Cell Biol 160, 189-200.

[74] Ishihara N, Nomura M, Jofuku A, Kato H, Suzuki SO, Masuda K, Otera H, Nakanishi Y, Nonaka I, Goto Y, Taguchi N, Morinaga H, Maeda M, Takayanagi R, Yokota S, Mihara K (2009) Mitochondrial fission factor Drp1 is essential for embryonic development and synapse formation in mice. Nat Cell Biol 11, 958-966.

[75] Chen H, McCaffery JM, Chan DC (2007) Mitochondrial fusion protects against neurodegeneration in the cerebellum. Cell 130, 548-562.

[76] Nguyen PV, Marin L, Atwood HL (1997) Synaptic physiology and mitochondrial function in crayfish tonic and phasic motor neurons. J Neurophysiol 78, 281-294.

[77] Billups B, Forsythe ID (2002) Presynaptic mitochondrial calcium sequestration influences transmission at mammalian central synapses. J Neurosci 22, 5840-5847.
[78] David G, Barrett EF (2003) Mitochondrial Ca2 + uptake prevents desynchronization of quantal release and minimizes depletion during repetitive stimulation of mouse motor nerve terminals. J Physiol 548, 425-438.

[79] Talbot JD, David G, Barrett EF (2003) Inhibition of mitochondrial $\mathrm{Ca} 2+$ uptake affects phasic release from motor terminals differently depending on external $[\mathrm{Ca} 2+]$. J Neurophysiol $\mathbf{9 0}$, 491-502.

[80] Tang Y, Zucker RS (1997) Mitochondrial involvement in posttetanic potentiation of synaptic transmission. Neuron 18, 483491.

[81] Li Z, Okamoto K, Hayashi Y, Sheng M (2004) The importance of dendritic mitochondria in the morphogenesis and plasticity of spines and synapses. Cell 119, 873-887.

[82] Braak H, Braak E, Kalus P (1989) Alzheimer's disease: areal and laminar pathology in the occipital isocortex. Acta Neuropathol 77, 494-506.

[83] Koivunen J, Verkkoniemi A, Aalto S, Paetau A, Ahonen JP, Viitanen M, Nagren K, Rokka J, Haaparanta M, Kalimo H, Rinne JO (2008) PET amyloid ligand [11C]PIB uptake shows predominantly striatal increase in variant Alzheimer's disease. Brain 131, 1845-1853.

[84] Love S, Wilcock GK, Matthews SM (1996) No correlation between nigral degeneration and striatal plaques in Alzheimer's disease. Acta Neuropathol 91, 432-436.

[85] Suenaga T, Hirano A, Llena JF, Yen SH, Dickson DW (1990) Modified Bielschowsky stain and immunohistochemical studies on striatal plaques in Alzheimer's disease. Acta Neuropathol 80, 280-286.

[86] Brustovetsky N, Brustovetsky T, Purl KJ, Capano M, Crompton M, Dubinsky JM (2003) Increased susceptibility of striatal mitochondria to calcium-induced permeability transition. J Neurosci 23, 4858-4867.

[87] Nishino H, Hida H, Kumazaki M, Shimano Y, Nakajima K, Shimizu H, Ooiwa T, Baba H (2000) The striatum is the most vulnerable region in the brain to mitochondrial energy compromise: a hypothesis to explain its specific vulnerability. $J$ Neurotrauma 17, 251-260.

[88] Hauptmann S, Scherping I, Drose S, Brandt U, Schulz KL, Jendrach M, Leuner K, Eckert A, Muller WE (2009) Mitochondrial dysfunction: an early event in Alzheimer pathology accumulates with age in AD transgenic mice. Neurobiol Aging 30, 1574-1586.

[89] Caspersen C, Wang N, Yao J, Sosunov A, Chen X, Lustbader JW, Xu HW, Stern D, McKhann G, Yan SD (2005) Mitochondrial Abeta: a potential focal point for neuronal metabolic dysfunction in Alzheimer's disease. FASEB J 19, 2040-2041. 